\title{
Effect of Alligator Pepper on Litter Weight of Rats Fed on High Glycemic Index Diet
}

\author{
Ute Inegbenebor*, Festus Eghomwanre \\ Department of Physiology, Faculty of Basic Medical Sciences, College of Medicine, Ambrose Alli University, Ekpoma, Nigeria \\ Email: *druteinegbenebor@yahoo.com, Deboreal451@gmail.com
}

How to cite this paper: Inegbenebor, U. and Eghomwanre, F. (2017) Effect of Alligator Pepper on Litter Weight of Rats Fed on High Glycemic Index Diet. Food and Nutrition Sciences, 8, 793-800.

https://doi.org/10.4236/fns.2017.88056

Received: May 15, 2017

Accepted: July 30, 2017

Published: August 2, 2017

Copyright $\odot 2017$ by authors and Scientific Research Publishing Inc. This work is licensed under the Creative Commons Attribution International License (CC BY 4.0).

http://creativecommons.org/licenses/by/4.0/

\begin{abstract}
This study was carried out to find out if alligator pepper can prevent the development of fetal macrosomia in Sprague-Dawley rats fed with high glycemic index diet. Fifteen adult female Sprague-Dawley rats of proven fertility were acclimatized for a period of two weeks in a well-ventilated laboratory and fed with grower's mash and water ad libitum. Thereafter, they were randomly placed in separate cages after which a male Sprague-Dawley rat of proven fertility was introduced into each of the cages containing the female rats. They were left in the cages for three days during, which mating was confirmed to have occurred. The male rats were then withdrawn from the female rats, which were placed in separate maternity cages. The female rats were randomly allocated to three groups A, B and C so there were 5 pregnant rats in each group. The rats in group A were fed with $50 \mathrm{~g}$ of grower's mash daily while the rats in groups B and C were fed with $50 \mathrm{~g}$ of cooked fermented cassava respectively. All rats were given water ad libitum throughout the duration of the experiment. The rats in groups A and B were intraperitoneally injected with $13.3 \mathrm{ml}$ per $\mathrm{Kg}$ body weight of distilled water while the rats in group $\mathrm{C}$ were intraperitoneally injected with $13.3 \mathrm{mg} / \mathrm{Kg}$ body weight of aqueous extract of alligator pepper respectively. They were observed for $18-25$ days. The litters of the rats in group B had a significantly higher mean weight than the rats in group A while the litters of the rats in group $C$ had a significantly lower mean weight than the rats in groups B. It was concluded that intraperitoneally injected aqueous extract of alligator pepper, in the first trimester of pregnancy, can prevent the development of fetal macrosomia in Sprague-Dawley rats.
\end{abstract}

\section{Keywords}

Effect, Alligator Pepper, High Glycemic Index Diet, Litter Weight, Sprague Dawley Rat 


\section{Introduction}

Alligator pepper (Aframomum melegueta) is a widely used spice in several parts of the world. Also known as grains of paradise. Aframomum melegueta, a species of the ginger family, contains pungent, aromatic ketones such as 6-paradol, 6-gingerol and 6-shogaol [1]. This is in addition to sesquiterpenes and non terpenoids [2].

In Eastern Europe and Asia it is used as a dietary spice. It is often sprinkled over food for its spice, flavor and fragrance. In Nigeria, it is used as an ingredient in the preparation of meat sauce locally called "pepper soup", for its inviting aroma. It is also served along with kola nuts as entertainment in many cultures and as communion in Iyayi (Faith) Society of Nigeria. Pregnant women are not excluded from these practices [3].

Glycemic index measures how a carbohydrate-containing food raises blood glucose in comparison to glucose itself [4]. Foods, which after digestion produce large quantities of glucose, are called high glycemic index foods. These include white rice [5], white bread [4] and cooked fermented cassava [6]. Excessive ingestion of such foods increases the glycemic load of that food. The result of chronic ingestion of large quantities of high glycemic index diets by pregnant women is the increased prevalence of fetal macrosomia [7]. In a previous study, it was found that the prevalence of Large for gestational weight babies was 33\% among the pregnant women fed on high glycemic index diet when compared to $3.1 \%$ among pregnant women fed on low glycemic index diet. This was considered significant at $\mathrm{p}<0.01[7]$.

Though fetal macrosomia has been defined as birth-weight over $4000 \mathrm{~g}$ irrespective of gestational age or greater than the 90th percentile for gestational age after correcting for neonatal sex and ethnicity [8], there is currently no consensus in the definition among researchers and obstetricians [9]. It predisposes to prolonged and difficult labor, the consequence of which is a high rate of maternal morbidity and mortality. Hence fetal macrosomia often tasks the efforts of health care providers including obstetricians, thereby increasing costs of management. Some complications of fetal macrosomia may predispose to a lifelong disability with socio-economic consequences [10].

In a previous study, intraperitoneally injected aqueous extract of alligator pepper was found to reduce gestational weight gain and litter weight without adverse effects on both mother rats and litters [3]. Since excessive intake of high glycemic index foods during pregnancy (maternal over-nutrition) is believed to predispose to the development of fetal macrosomia [11], this study was carried out to determine the effect of a locally available high glycemic index food (cooked fermented cassava) on birth weight of litters of pregnant Sprague Dawley rats. There was also a need to find out if the birth of macrosomic litters by pregnant Sprague Dawley rats fed with high glycemic index food could be prevented with intraperitoneally injected aqueous extract of alligator pepper. 


\section{Materials and Methods}

\subsection{Materials}

The materials used during the course of this study include granulated seeds of alligator pepper, cooked fermented cassava, pelleted grower's mash, drinking trough, electronic weighing scale, filter paper, beakers, funnel, syringe/needles and anticoagulant bottles. The pelleted grower's mash, produced by Grand cereals Ltd., a subsidiary of UAC Nigeria PLC, Jos, Nigeria was purchased from a store in Ekpoma market.

\subsection{Methods}

Fifteen adult female Sprague-Dawley rats of proven fertility were acclimatized for a period of two weeks in a well-ventilated laboratory and fed with grower's mash and water ad libitum. Thereafter, they were randomly placed in separate cages after which a male Sprague Dawley rat of proven fertility was introduced into each of the cages containing the female rats. They were left in the cages for three days during, which mating was confirmed to have occurred, using a method previously used by Ojieh et al. [12] The male rats were then withdrawn from the female rats, which were placed in separate maternity cages. The female rats were randomly allocated to three groups A, B and C so there were 5 pregnant rats in each group. The rats in group A were fed with $50 \mathrm{~g}$ of growers mash daily while the rats in groups B and C were respectively fed with $50 \mathrm{~g}$ of cooked fermented cassava daily. All rats were given water ad libitum throughout the duration of the experiment.

\subsection{Preparation and Administration of the Extract}

Twenty (20) mg of granulated seeds of alligator was mixed thoroughly with 20 $\mathrm{ml}$ of distilled water, allowed to stand for 2 hours and filtered into a beaker. This filtrate was then administered to the pregnant Sprague-Dawley rats intraperitoneally as was previously reported by Inegbenebor and colleagues in 2009 [3]. Since $20 \mathrm{ml}$ of aqueous extract was obtained from $20 \mathrm{mg}$ of granulated seeds of alligator pepper, I ml. of aqueous extract is obtainable from $1 \mathrm{mg}$ of granulated seeds of alligator pepper. The implication is that $1 \mathrm{ml}$ of the extract was assumed to be equivalent to I $\mathrm{mg}$ of granulated seeds of alligator pepper.

The rats in groups A and B were intraperitoneally injected with $13.3 \mathrm{ml}$ per $\mathrm{Kg}$ body weight of distilled water while the rats in group $\mathrm{C}$ were intraperitoneally injected with $13.3 \mathrm{mg}$ per $\mathrm{Kg}$ body weight of aqueous extract of alligator pepper respectively on day 4 of gestation. They were observed for 18 - 25 days.

\subsection{Data Analysis}

This was done by cross tabulation, Analysis of Variance of all groups and test of significance of the difference of means between groups B and A and also between groups C and B using Daniel Soper's free software for the calculation of $\mathrm{F}$ and $\mathrm{p}$ values [13]. 


\section{Results}

The litters of the pregnant rats in group B, which were fed with cooked fermented cassava and were treated with intraperitoneal injection of distilled water, had a significantly higher weight than the litters of the pregnant rats in group A, which were fed with grower's mash and were also treated with distilled water ( $p$ $<0.05)$. The litters of the pregnant rats in group $C$, which were fed with an equal weight of cooked fermented cassava but were treated with intraperitoneal injection of aqueous extract of the seeds of alligator pepper, had a significantly lower weight than the litters of the pregnant rats in groups $B(p<0.05)($ Table 1$)$.

\section{Discussion}

High glycemic index foods are commonly used as staple foods in many parts of the world [5] [14] [15]. This is probably because of their energy yielding characteristic, which ensures that there is enough strength to carry out daily activities [16]. When high glycemic index foods are consumed excessively, there is conversion of the excess post digestion glucose to fat, which is stored in the adipose tissue [16]. Regular ingestion of excessive quantities of high glycemic index foods eventually results in excessive weight gain, the ultimate of which is obesity [17]. When high glycemic index foods are consumed excessively in pregnancy, the result is excessive gestational weight gain, which is one of the predisposing factors of fetal macrosomia [18].

In a previous study, it was found that oral ingestion of high doses of granulated seeds of alligator pepper ( $333 \mathrm{mg} / \mathrm{Kg}$ body weight) caused termination of first trimester pregnancies in Sprague-Dawley rats [19], while intraperitoneal injection of low dose of the aqueous extract of the seeds of alligator pepper on the 4 th day of gestation caused attenuation of gestational weight gain in mother rats and a reduction in litter weight of their litters without adverse effects on either mother rats or their litters [3]. These rat chow used in the previous study was grower's mash, which was also used in feeding the rats in the control group A in this study. Since the alligator pepper treated pregnant rats in the previous study, which were not exposed to high glycemic diet gave birth to litters which had significantly lower birth weight than the pregnant rats in the control group [3], it

Table 1. Effect of aqueous extract of alligator pepper on litter weight of pregnant rats fed with cooked fermented cassava.

\begin{tabular}{|c|c|c|c|c|c|}
\hline Group & $\begin{array}{l}\text { Type of food } \\
\text { administered }\end{array}$ & $\begin{array}{l}\text { Weight of } \\
\text { Food adminis- } \\
\text { tered in grams }\end{array}$ & $\begin{array}{l}\text { Dose of alligator } \\
\text { pepper in } \mathrm{mg} / \mathrm{Kg} \\
\text { body weight }\end{array}$ & $\begin{array}{l}\text { No. of } \\
\text { litters }\end{array}$ & $\begin{array}{l}\text { Mean weight of } \\
\text { litters in grams }\end{array}$ \\
\hline$A[n=5]$ & Grower's mash & $50 \mathrm{~g}$ & Nil & 15 & $3.80 \pm 0.23$ \\
\hline $\mathrm{B}[\mathrm{n}=5]$ & $\begin{array}{c}\text { Cooked fermented } \\
\text { cassava }\end{array}$ & $50 \mathrm{~g}$ & Nil & 19 & $6.20 \pm 0.72^{\star}$ \\
\hline$C[n=5]$ & $\begin{array}{c}\text { Cooked fermented } \\
\text { cassava }\end{array}$ & $50 \mathrm{~g}$ & 13.3 & 18 & $4.20 \pm 0.40^{\star *}$ \\
\hline
\end{tabular}

${ }^{*}$ Significant increase in litter weight $(\mathrm{p}<0.05) ;{ }^{*}$ Significant decrease in litter weight $(\mathrm{p}<0.05)$. 
was necessary to find out if intraperitoneally injected aqueous extract of the seeds of alligator pepper would have the same effect on the litters of pregnant rats, which were exposed to high glycemic index diet in this study. This finding was expected to experimentally support the hypothesis that prevention of fetal macrosomia was possible with the intraperitoneal injection of aqueous extract of the seeds of alligator pepper in Sprague-Dawley rats in the first trimester of pregnancy.

A cursory observation of the number of litters produced by the rats in each of the study groups would reveal that the average number of litters was lower than that reported in the previous study [3]. This may be due to environmental factors and seasonal variations, as the two studies were performed in different laboratories at different seasons of the year. The previous study [3], was carried out during the rainy season (July to August) while the present study was carried out in the dry season (February to March). This finding is consistent with a previous study, which found that there are seasonal variations in the fecundity of rats, noting that fecundity peaks between May and August while it reaches a nadir between December and February [20]. Furthermore, there was a pilot study in the previous study where the mother rats with the highest fecundity were selected for the definitive study [3].

In this study, the mean litter weight of pregnant rats in group B, which were fed with cooked fermented cassava, a locally available high glycemic index food in Nigeria was significantly higher than the mean litter weight of pregnant rats in the control group A, which were fed with an equal weight of grower's mash. The end products of insulin enhanced glycolysis are alpha-glycerophosphate and free fatty acids. Free fatty acid is esterified by alpha-glycerophosphate to form triglyceride thereby increasing fat mass [16]. Insulin enhances protein anabolism by facilitating amino acid uptake and protein synthesis while depressing gluconeogenesis [21]. This effect increases the size of muscles [16]. Insulin like growth factor 1 (Igf1) increases longitudinal bone growth by facilitating chondrocyte hypertrophy [22]. This is the precursor of the shoulder dystocia that makes the delivery of macrosomic babies an enigma [23].

When aqueous extract of alligator pepper was administered to pregnant rats in group C, which were fed on cooked fermented cassava, the mean litter weight was significantly lower than mean litter weight of the untreated pregnant rats in group B, which were also fed on an equal weight of cooked fermented cassava. This is consistent with the result of a previous study where intraperitoneally injected aqueous extract of the seeds of alligator pepper was found to reduce litter weight of pregnant Sprague-Dawleyrats fed on normal rat chow [3].

In a recent study in 2014, Owokotomo and colleagues, found that the essential oil, from the seeds of alligator pepper, contains nine constituents (mainly $\alpha$-caryophyllene (48.78\%), $\beta$-caryophyllene (32.50\%) and linalool (5.40\%)) [24]. Beta caryophyllene has been found to be a type 2 beta cannabinol receptor agonist and caryophyllene has been approved as a food additive by Food and Drug Administration of United States of America [25] [26]. 
At the transcriptional level, peroxisome proliferator-activated receptor-gamma coactivator $1 \alpha$ (PGC-1 $\alpha$ ) has been reported to strongly increase the ability of hormone nuclear receptors peroxisome proliferator activated receptor (PPAR $\alpha$ ) and estrogen receptor (ERR $\alpha$ ) to drive transcription of fatty acid oxidation enzymes [27]. Zheng et al. reported that specific agonist of the type 2 cannabinoid receptor $(\mathrm{CB} 2 \mathrm{R})$ can lead to fatty acid oxidation through the PGC-1 $\alpha$ pathway. Use of the specific agonist trans-caryophyllene stimulates sirtuin 1deacety laseactivity by increasing the phosphorylation of cyclic adenosine monophosphate response element-binding protein (CREB), thus leading to increased levels of PGC- $1 \alpha$ deacetylation. Activation of CB2Rby a selective agonist promotes lipid oxidation through a signaling/transcriptional pathway [27]. Since the aqueous extract of alligator pepper was not directly injected into the rat fetus, there is a possibility that caryophyllene constituent of alligator pepper crossed the placenta to induce a direct lipo-oxidative effect in the rat fetus. The other possibility is that the caryophyllene inhibits insulin release in the mother rat as observed in a previous study by Inegbenebor et al. [28], thereby reducing the quantity of glucose available to the fetus for conversion by fetal insulin to fat mass. It has also been found that consumption of the seeds of alligator pepper causes weight loss by increasing energy expenditure secondary to activation of brown adipose tissue [1]. Since brown adipose tissue is abundant in fetus and neonates, there is a possibility of this mechanism, being an alternative pathway by which alligator pepper prevents the development of fetal macrosomia in pregnant SpragueDawley rats.

\section{Conclusion}

It was concluded that high glycemic index foods are capable of inducing the development of fetal macrosomia in pregnant Sprague-Dawley rats. Also, intraperitoneally injected aqueous extract of the seeds of alligator pepper in the first trimester of pregnancy can prevent the development of fetal macrosomia in Sprague Dawley rats.

\section{References}

[1] Sugita, J., Yoneshiro, T., Hatano, T., Aita, S., Ikemoto, T., Uchiwa, H., Iwanaga, T., Ikameya, T., Kawai, Y. and Saito, M. (2013) Grains of Paradise (Aframomummelegueta) Extract Activates Brown Adipose Tissue and Increases Whole-Body Energy Expenditure in Men. British Journal of Nutrition, 110, 733-738. https://doi.org/10.1017/S0007114512005715

[2] Ajaiyeoba, O.E. and Ekundayo, O. (1999) Essential Oil Constituents of Aframomummelegueta (Roscoe) K. Schum Seeds (Alligator pepper) from Nigeria. Flavour and Fragrance Journal, 14, 109-111.

https://doi.org/10.1002/(SICI)1099-1026(199903/04)14:2<109::AID-FFJ775>3.0.CO; $\underline{2-\mathrm{M}}$

[3] Inegbenebor, U., Ebomoyi, M.I., Onyia, K.A., Amadi, K. and Aigbiremolen, A.E. (2009) Effect of Alligator Pepper (Zingaberaciae Aframomummeligueta) on Gestational Weight Gain. Nigerian Journal of Physiological Sciences, 24, 165-169. 
[4] American Diabetic Association (2017) Glycemic Index and Diabetes. http://www.diabetes.org/food-and-fitness/food/what-can-i-eat/understanding-carb ohydrates/glycemic-index-and-diabetes.html?referrer=https://search.yahoo.com/.

[5] Asinobi, C., Uzoagba, H., Mba-Anyadioha, A. and Johnkennedy, N. (2016) Effects of Commonly Consumed Traditional Fortified Staple Meals on the Postprandial Blood Glucose Responses of Undergraduate Students in Imo State University, Owerri, Imo State, Nigeria: An Open-Label Study. Functional Foods in Health and Disease, 6, 414-424.

[6] Ihediohanma, N.C. (2011 Determination of the Glycemic Indices of Three Different Cassava Granules (Garri) and the Effect of Fermentation Period on Their Glycemic Responses. Pakistan Journal of Nutrition, 10, 6-9. https://doi.org/10.3923/pjn.2011.6.9

[7] Moses, R.G., Luebcke, M., Davis, W.S., Coleman, K.J., Tapsell, L.C., Petocz, P. and Brand-Miller, J.C. (2006) Effect of a Low-Glycemic-Index Diet During Pregnancy on Obstetric Outcomes. American Journal of Clinical Nutrition, 84, 807-812.

[8] Mohammadbeigi, A., Farhadifar, F., Soufizadeh, N., Mohammadsalehi, N., Rezaiee, M. and Aghaei, M. (2013) Fetal Macrosomia: Risk Factors, Maternal, and Perinatal Outcome. Annals of Medical Health Sciences and Research, 3, 546-550. https://doi.org/10.4103/2141-9248.122098

[9] Ye, J., Torloni, M.R., Ota, E., Jayaratne, K., Castro, C.P., Ortiz-Panozo, E., Lumbiganon, P., Morisaki, N., Laopaiboon, M., Mori, R., Tunçalp, O., Fang, F., Yu, H., Souza, J.P., Vogel, J.P. and Zhang, J. (2015) Searching for the Definition of Macrosomia through an Outcome-Based Approach in Low- and Middle-Income Countries: A Secondary Analysis of the WHO Global Survey in Africa, Asia and Latin America. BMC Pregnancy Childbirth, 15, 324.

[10] Vasudevan, C., Renfrew, M. and McGuire, W. (2011) Fetal and Perinatal Consequences of Maternal Obesity. Archives of Disease in Childhood, 96, F378-F382.

[11] Drake, A.J. and Reynolds, R.M. (2010) Impact of Maternal Obesity on Offspring Obesity and Cardio-Metabolic Disease Risk. Reproduction, 140, 387-398. https://doi.org/10.1530/REP-10-0077

[12] Ojieh, E.A., Adegor, C.E. and Ewhre, O.L. (2013) Regulated Effects of Capsicum frutescens Supplemented Diet (C.F.S.D) on Fasting Blood Glucose Level, Biochemical Parameters and Body Weight in Alloxan Induced Diabetic Wistar Rats. British Journal of Pharmaceutical Research, 3, 496-507. https://doi.org/10.9734/BJPR/2013/3256

[13] Soper, D. (2015) The Free Statistics Calculators Website. http://www.danielsoper.com/statcalc3/

[14] Vaidya, R., Mohan, V., Bai, M.R. and Vasudevan, S. (2014) Glycemic Index of Indian CerealStaple Foods and their Relationship to Diabetes and Metabolic Syndrome. Wheat and Rice in Disease Prevention and Health. London. Academic Press, Elsevier Inc., New York, 333-346. https://doi.org/10.1016/B978-0-12-401716-0.00025-8

[15] Manore, M.M., Mason, M.B.S. and Skoog, I.M.S. (2004) A Nutritionist's View: Applying the Concepts of Glycemic Index and Glycemic Load to Active Individuals. ACSMS Health \& Fitness Journal, 8, 21-23. https://doi.org/10.1097/00135124-200409000-00008

[16] Bullock, J. (2003) Biochemical Actions of Insulin. In: Bullock, J., Boyle, J. and Wang, C., Eds., Physiology, 4th Edition, National Medical Series for Independent Study, Lippincott Williams and Wilkins, Baltimore, 674-675. 
[17] Brand-Miller, J.C., Holt, S.H.A., Pawlak, D.B. and McMillan, J. (2002) Glycemic Index and Obesity. American Journal of Clinical Nutrition, 76, 281S-285S.

[18] Kim, S.Y., Sharma, A.J., Sappenfield, W., Wilson, H.G. and Salihu, H.M. (2014) Association of Maternal Body Mass Index, Excessive Weight Gain, and Gestational Diabetes Mellitus with Large-for-Gestational-Age Births. Contributions to Largefor-Gestational-Age Births. Obstetrics and Gynecology, 123, 737-744. https://doi.org/10.1097/AOG.0000000000000177

[19] Inegbenebor, U., Ebomoyi, M.I., Onyia, K.A., Amadi, K. and Aigbiremolen, A.E. (2009a) Effect of Alligator Pepper (Zingiberaceae Aframomum melegueta) on First Trimester Pregnancy in Sprague Dawley Rats. Nigerian Journal of Physiological Sciences, 24, 161-164.

[20] Lee, T.M. and McClintock, M.K. (1986) Female Rats in a Laboratory Display Seasonal Variation in Fecundity. Journal of Reproduction and Fertility, 77, 51-59. https://doi.org/10.1530/jrf.0.0770051

[21] Girard. J. (2006) The Inhibitory Effects of Insulin on Hepatic Glucose Production Are Both Direct and Indirect. Diabetes, 55, S65-S69. https://doi.org/10.2337/db06-S009

[22] Wang, J., Zhou, J. and Bondy, C.A. (1999) Igf 1 Promotes Longitudinal Bone Growth by Insulin-Like Actions Augmenting Chondrocyte Hypertrophy. The Federation of American Societies for Experimental Biology Journal, 13, 1985-1990.

[23] Resnik, R. (2003) Fetal Macrosomia: 3 Management Dilemmas. OBG Management, $15,28-36$.

[24] Owokotomo, A., Ekundayo, O. and Oguntuase, B.J. (2014) Chemical Constituents of the Leaf, Stem, Root and Seed Essential Oils of Aframomum melegueta (K. Schum) from South West Nigeria. International Research Journal of Pure and Applied Chemistry, 4, 395-401. https://doi.org/10.9734/IRJPAC/2014/7397

[25] Gertsch, J., Leonti, M., Raduner, S., RaIcz, I., Chen, J.Z., Xie, X.Q., Altman, K.H., Karsak, M. and Zimmer, A. (2008) Beta-Caryophyllene Is a Dietary Cannabinoid. Proceedings of National Academy of Sciences of the United States of America, 105, 9099-9104. https://doi.org/10.1073/pnas.0803601105

[26] Fiorenzani, P., Lamponi, S., Magnani, A., Ceccarelli, I. and Aloisi A.M. (2014) In Vitro and In Vivo Characterization of the New Analgesic Combination Beta-Caryophyllene and Docosahexaenoic Acid. Evidence-Based Complementary and Alternative Medicine, 2014, Article ID: 596312, 12 p.

[27] Zheng, X., Sun, T. and Wang, X. (2013) Activation of Type 2 Cannabinoid Receptors (CB2R) Promotes Fatty Acid Oxidation through the SIRT1/PGC-1a Pathway. Biochemical and Biophysical Research Communications, 436, 377-381. https://doi.org/10.1016/j.bbrc.2013.05.108

[28] Inegbenebor, U., Ebomoyi, M.I. and Obika, L.F.O. (2016) Determining the Physiological Basis of the Effects of Alligator Pepper in Pregnant Sprague Dawley Rats. Jacob's Journal of Plant Biology, 1, 1-7. 
Submit or recommend next manuscript to SCIRP and we will provide best service for you:

Accepting pre-submission inquiries through Email, Facebook, LinkedIn, Twitter, etc. A wide selection of journals (inclusive of 9 subjects, more than 200 journals)

Providing 24-hour high-quality service

User-friendly online submission system

Fair and swift peer-review system

Efficient typesetting and proofreading procedure

Display of the result of downloads and visits, as well as the number of cited articles Maximum dissemination of your research work

Submit your manuscript at: http://papersubmission.scirp.org/

Or contact fns@scirp.org 